\title{
FRACTURE MECHANICS UNCERTAINTY ANALYSIS IN THE RELIABILITY ASSESSMENT OF THE REACTOR PRESSURE VESSEL: (2D) SUBJECTED TO INTERNAL PRESSURE
}

\author{
Entin Hartini, Roziq Himawan, Mike Susmikanti \\ Center for Nuclear Reactor Technology and Safety, Kawasan Puspiptek, Tangerang Selatan, 15310 \\ E-mail: entin@batan.go.id \\ Diterima editor: 7 Maret 2016 \\ Diperbaiki: 2 Juni 2016 \\ Disetujui untuk publikasi: 6 Juni 2016
}

\begin{abstract}
FRACTURE MECHANICS UNCERTAINTY ANALYSIS IN THE RELIABILITY ASSESSMENT OF THE REACTOR PRESSURE VESSEL: (2D) SUBJECTED TO INTERNAL PRESSURE. The reactor pressure vessel (RPV) is a pressure boundary in the PWR type reactor which serves to confine radioactive material during chain reaction process. The integrity of the RPV must be guaranteed either in a normal operation or accident conditions. In analyzing the integrity of RPV, especially related to the crack behavior which can introduce break to the reactor pressure vessel, a fracture mechanic approach should be taken for this assessment. The uncertainty of input used in the assessment, such as mechanical properties and physical environment, becomes a reason that the assessment is not sufficient if it is perfomed only by deterministic approach. Therefore, the uncertainty approach should be applied. The aim of this study is to analize the uncertainty of fracture mechanics calculations in evaluating the reliability of PWR's reactor pressure vessel. Random character of input quantity was generated using probabilistic principles and theories. Fracture mechanics analysis is solved by Finite Element Method (FEM) with MSC MARC software, while uncertainty input analysis is done based on probability density function with Latin Hypercube Sampling (LHS) using python script. The output of MSC MARC is a J-integral value, which is converted into stress intensity factor for evaluating the reliability of RPV's 2D. From the result of the calculation, it can be concluded that the SIF from probabilistic method, reached the limit value of fracture toughness earlier than SIF from deterministic method. The SIF generated by the probabilistic method is $105.240 \mathrm{MPa} \mathrm{m} \mathrm{m}^{0.5}$. Meanwhile, the SIF generated by deterministic method is $100.876 \mathrm{MPa} \mathrm{m}^{0.5}$.
\end{abstract}

Keywords: Uncertainty analysis, fracture mechanics, LHS, FEM, reactor pressure vessels

\begin{abstract}
ABSTRAK
ANALISIS KETIDAKPASTIAN FRACTURE MECHANIC PADA EVALUASI KEANDALAN BEJANA TEKAN REAKTOR: 2D DENGAN BEBAN INTERNAL PRESSURE. Bejana tekan reaktor (RPV) merupakan pressure boundary dalam reaktor tipe PWR yang berfungsi untuk mengungkung material radioaktif yang dihasilkan pada proses reaksi berantai. Maka dari itu integritas bejana tekan reaktor harus senantiasa terjamin baik reaktor dalam keadaan operasi normal, maupun kecelakaan. Dalam melakukan analisis integritas RPV, khususnya yang berkaitan dengan pecahnya bejana tekan reaktor akibat adanya retak dilakukan analisis secara fracture mechanics. Adanya ketidakpastian input seperti sifat mekanik bahan, lingkungan fisik, dan input pada data, maka dalam melakukan analisis keandalan tidak hanya dilakukan secara deterministik saja. Tujuan dari penelitian ini adalah melakukan analisis ketidakpastian input pada perhitungan fracture mechanik pada evaluasi keandalan bejana tekan reaktor PWR. Pendekatan untuk karakter random dari kuantitas input menggunakan teori probabilistik. Analisis fracture mechanics dilakukan berdasarkan metode elemen hingga (FEM) menggunakan perangkat lunak MSC MARC. Analisis ketidakpastian input dilakukan berdasarkan probability density function dengan Latin Hypercube Sampling (LHS) menggunakan python script. Output dari MSC MARC adalah nilai J-integral untuk mendapatkan nilai stress intensity factor pada evaluasi keandalan bejana tekan reactor 2D. Dari hasil perhitungan dapat disimpulkan bahwa SIF probabilistik lebih dulu mencapai nilai batas fracture tougness dibanding SIF deterministik. SIF yang dihasilkan dengan metode probabilistik adalah 105,240 MPa m ${ }^{0,5}$. Sedangkan SIF metode deterministik adalah 100,876 MPa $\mathrm{m}^{0,5}$.
\end{abstract}

Kata kunci: Analisis ketidakpastian, fracture mechanics, LHS, FEM, bejana tekan reaktor 


\section{INTRODUCTION}

The operation of nuclear power plant (NPP) is always required to put a safety as priority, both to workers and communities around nuclear power plants. In order to minimize the probability of radioactive releases into the environment, nuclear power plant confinement is designed with several barriers. One of the barrier is reactor pressure vessel [1-2]. The reactor pressure vessel is a pressure boundary in the pressurized water reactor (PWR) type, which serves as third barrier in the confinement of radioactive material resulting from chain reactions. Therefore, the integrity of the reactor pressure vessel must be guarant either in a normal operation or accident conditions [1-3].

Reliability assessment methods for reactor pressure vessel have been already developed based on deterministic fracture mechanic techniques. In practice, for analizing the material reliability or predicting the possibility of material failure, the initial conditions of the system are not known precisely due to uncertainties. To accomodate the uncertainties, a probabilistic method can be used, therefore the calculation of safety margin take into account the uncertainty of input that will affect the output value $[1,2,4,7]$. Uncertainty analysis includes physical variables of the loading conditions, such as internal pressure and material properties [7-11].

In the fracture mechanics calculation of reactor pressure vessel, material property and loading should be considered as the uncertainty factors. Therefore, reliability assessment of reactor pressure vessel should be conducted by probabilistic techniques. The purpsose of this study is to evaluate the reliability of PWR's reactor pressure vessel with fracture mechanics analysis by introducing uncertainty. Research was limited on reliability evaluation of the 2 Dimensional (2D) model of pressure vessel wall with the internal pressure loading conditions in which the pressure vessel modeled as plate and there is crack translucent on the surface with the axial direction. Crack lengths from the edge used in this simulation are about $100 \mathrm{~mm}, 200 \mathrm{~mm}$ and $300 \mathrm{~mm}$. The use of three crack lengths is to examine the critical crack length.

The investigated pressure vessel wall material was ferritic steel (SA 533). Calculation of fracture mechanics ( $\mathrm{J}$ integral) was performed using the software MSC MARC $[12,13]$ with additional latin hypercube sampling (LHS) method used for the uncertainty analysis. The final results of this research were the value of stress intensity factor and the estimated probability of failure for the evaluation of the reliability of PWR reactor pressure vessel. The output of MSC MARC is a J-integral value, which is then converted into stress intensity factor for evaluating the reliability of RPV's 2D.

\section{THEORY}

The purpose of the sampling technique is to produce matrix $X^{n}=\left(x_{i}^{j}\right), i=1, .,, n$ and $j$ $=1, .$, ., $p$, where $n$ is the number of trials and $p$ is the number of variables. The most common sampling method is the Monte Carlo (MC), mainly because of its simplicity. LHS is an alternative method of generating $X^{n}$. It is an extension of stratified sampling. LHS method ensure that each of the input variables have all the range represented [17]. Each variable $X_{j}, j=1 \ldots p$, simultaneously divided into $\mathrm{n}$ interval probabilities. $X_{i}^{j}$ is $\mathrm{n}$ sample of $X_{j}$ variables with $n$ size. There is a $p$ column of the matrix $n x p$ of experiment $\mathrm{X}^{\mathrm{n}}$ generated by LHS. Row $\mathrm{i}^{\text {th }}$ of the matrix contains $\mathrm{p}$ input variables and will consistent with the code execution of $i$. Mathematically, if $X_{1}, ., \ldots$, ., $X_{p}$ are independent random variables with continuous distribution function $F_{j}, j=1, ., \ldots, ., p$, then the $\mathrm{i}^{\text {th }}$ sample LHS for $\mathrm{j}^{\text {th }}$ variable can be written as [11] :

$$
x_{i}^{j}=F_{j}^{-1}\left(\frac{\pi_{j}^{(i)}-\zeta_{j}^{i}}{n}\right)
$$

Where $\pi_{j}$ uniform random permutation independent of integers $\{1,2, \ldots, \mathrm{n}\}$, and $\zeta_{i}^{j}$ is $\mathrm{U}[0,1]$ independent of the random number for $\pi_{j}$. 
Many computational models provide a good correspondence between the calculated and measured values. The evaluation process by means of linear elastic fracture mechanics method can not be regarded as a constant numerical value deterministically due to the existence of random characters. Accommodating the random characters of the input quantities into a calculation (the material characteristics, geometry, and the loading effect) leads to the application of the principles and methods of probabilistic theory.

Fracture mechanics is a method to assess the criticality of defects in the structure. Linear elastic fracture mechanics (LEFM) is a method of fracture behavior characteristic in structural parameters, stress, and size of defects that can be used directly. Fracture mechanics can be used to quantitatively describe the trade-off between pressure, material toughness, and the size of the defect. On the other hand, the stress intensity factor is a measure of changes in the stress around the crack tip. It is important to know the direction of crack and when the crack stops. Stress intensity factor is compared to the fracture toughness $K_{I C}$, to determine whether a crack will propagate or not. The stress intensity factor for fracture $K_{I}$, has the following form [7] :

$$
K_{I}=g \sigma \sqrt{\pi a}
$$

where: $\sigma=$ nominal stress,$a=1 / 2$ of the crack length and $\mathrm{g}=$ nondimensional function. $K_{I}$ can be used to compare the response of the same material at the crack tip (crack tips) and also to compare the extent in which the material is influenced by the stress field. Important parameters of linear elastic fracture mechanics is the fracture toughness, $K_{I C}$. Fracture toughness is the fracture characteristics of the material. If the plate is charged with failure stress $\sigma_{\mathrm{f}}$, and if $\sigma=\sigma_{\mathrm{f}}$ is the stress on the failure of the nominal value, then the $K_{I}$ value associated with $\sigma_{\mathrm{f}}$, can be determined as [7] :

$$
\sigma_{f}=\frac{K_{I C}}{\sqrt{\pi a}}
$$

Stress failure to crack length is shown in Figure 1, the plane stress condition $\mathrm{E}^{\prime}=\mathrm{E}$ and plane strain condition $\mathrm{E}^{\prime}=\mathrm{E} /\left(1-v^{2}\right)$, where $\mu$ is the Poisson ratio.

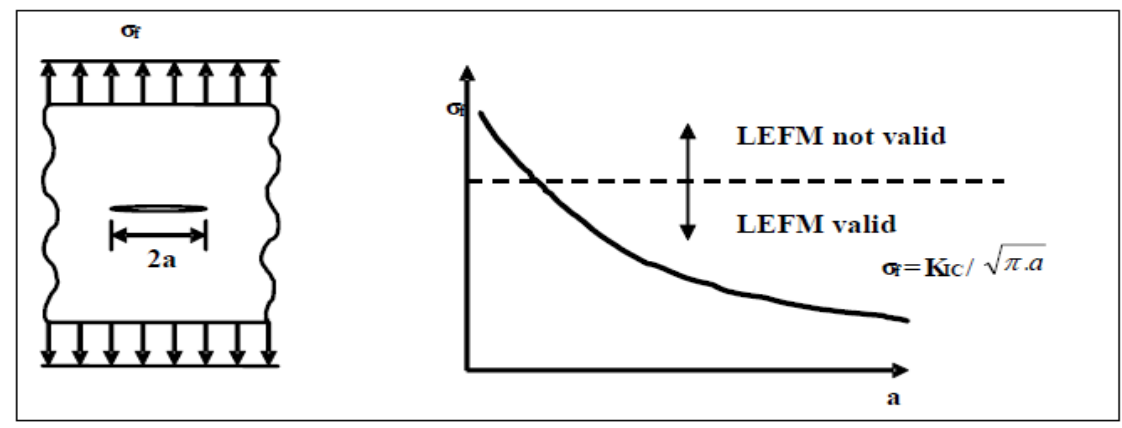

Figure 1. Stress Failure To crack length [7].

J-integral for 2-D deformation field (plane strain, plane stress) with pressure $\sigma_{\mathrm{ij}}$ depending on Cartesian coordinates $(\mathrm{x}, \mathrm{y})$. Axial semi-elliptical for inner surface defects assumed for each model and the aspect ratio of depth (a) with a length (2c). Models with defect depth $a / w=0.05$. The effect of thermal loads and pressure loads in the area of the crack can be included in the calculation of the J-integral. Stress intensity factor formula is [7] :

$$
K_{I}=\sqrt{\frac{E J}{1-v^{2}}}
$$

A model of this $\mathrm{J}$ integral calculate the vessel failure frequency and uncertainty about the failure frequency. uncertainty analysis of the input is done using (LHS). For analysis uncertainty of samples, the distribution type is taken from the relevant distribution (probability density function) 


\section{METHODOLOGY}

MSC MARC is used for the calculation of fracture mechanics of PWR pressure vessel. This calculation is done by deterministic and probabilistic approaches. In the simulations using MSC MARC steps being taken in prepocessor and post-processor are to define the geometry and make meshing. The next steps are to define material properties, to determine the initial crack position and boundary condition, to simulate the crack, and to select the display to be analyzed (e.g. J integral). The sample was the wall plates of the PWR pressure vessel that is material ferritic steel (SA 533) with a length of $5000 \mathrm{~mm}$ and width $1000 \mathrm{~mm}$ [15]. Poison ratio $(v)$ is 0.3 and Young's modulus (E) is $192 \times 10^{3} \mathrm{MPa}$ [15]. The load is distributed in component that works on the walls with pressure $\sigma$ at $75 \mathrm{Mpa}$. Internal pressure during operation of the reactor is $14 \mathrm{Mpa}-17 \mathrm{Mpa}$. Initial crack from the edge, in this simulation each round of $100 \mathrm{~mm}, 200 \mathrm{~mm}$ and $300 \mathrm{~mm}$. The $2 \mathrm{D}$ model simulation (plate) of the reactor pressure vessel is shown in Figure 2.

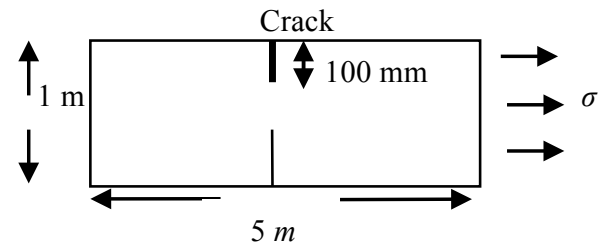

Figure 2. 2D Geometry of Sample Plates.

In the $\mathrm{J}$ integral probabilistic calculation, input data of material properties (modulus of elasticity) and loading parameters involves uncertainties. The LHS sampling to accommodate the uncertainty of the parameters involved in the calculation was performed by additional script using Python programming language [14].

After value of J-integral on MSC MARC is obtained, the next stage is to calculate stress intensity factor $\left(\mathrm{K}_{\mathrm{I}}\right)$ and to compare it to the $\mathrm{K}_{\mathrm{IC}}$. Flow chart for fracture mechanics analysis of the $\mathrm{RPV}$ is shown in Figure 3.

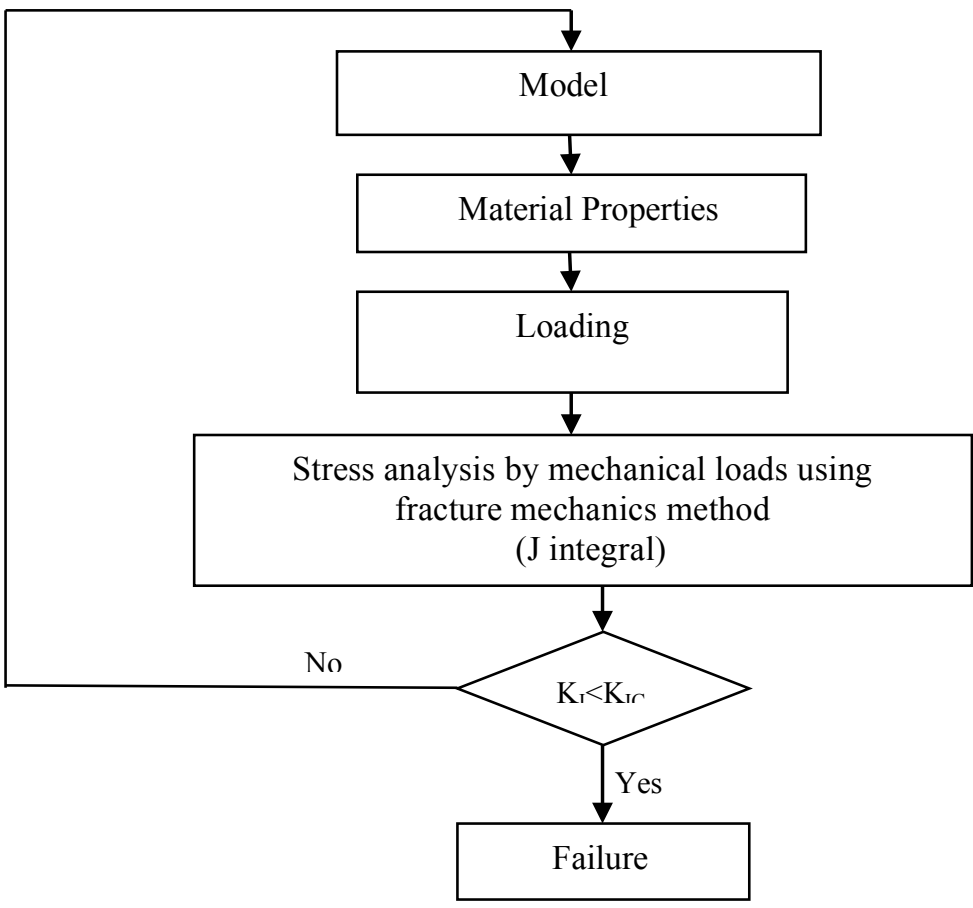

Figure 3. Flow chart of fracture mechanics analysis for RPV. 


\section{RESULTS AND DISCUSSION}

FEM model for calculating stress intensity factor of crack in the plate, simulating RPV's wall shows Figure 4. This model is a quarter model of the whole part of the plate, since the plate has two simetry axis. This model consists of 32 elements. The right direction of red arrow along the lower left edge of the model represents constraints of displacement, so that the displacement along $\mathrm{x}$-axis are not allowed. The halfupper left edge with no constraint symbol represents the length of the crack. It means that the middle point or node on the left edge represents a crack tip.

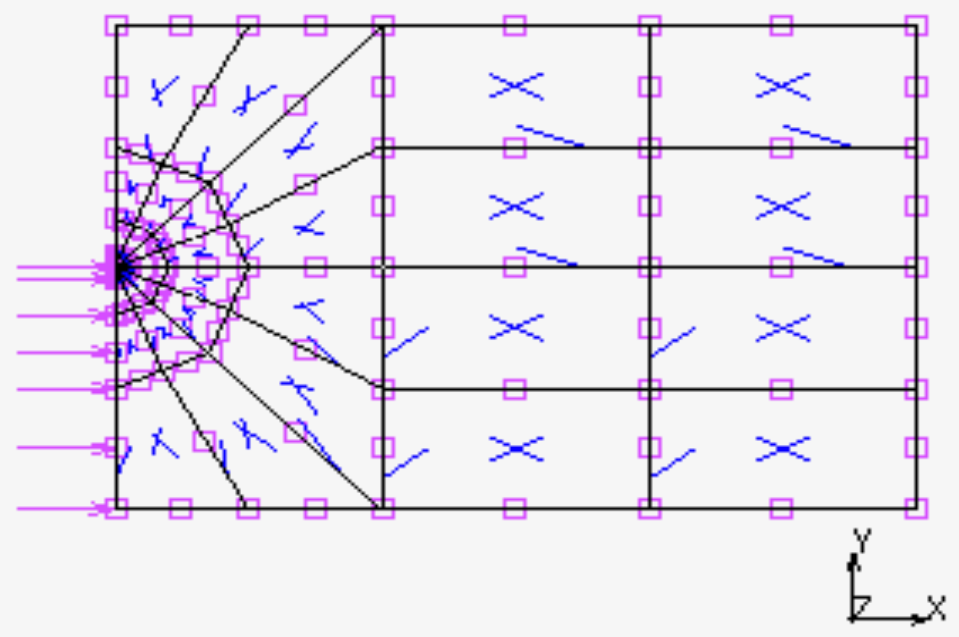

Figure 4. Results of Geometry Modeling of RPV's Wall.

Analysis results of $\mathrm{J}$ integral calculation for crack length $300 \mathrm{~mm}$ is shown in Figure 5. From this figure, it is known that the $\mathrm{J}$ integral value is 0.04832 . Then by using this value and equation (4), we could determined that the stress intensity factor $K_{I}$ was $100.876 \mathrm{MPa} \mathrm{m}^{0.5}$. In order to validate this result, a simple calculation of stress intensity factor uses Equation (3). This calculation resulted the $K_{I}$ value of $102.135 \mathrm{M} . \mathrm{Pa} \mathrm{m}{ }^{0.5}$. Comparing the FEM analysis result to calculation result, there is the difference in value of 0.01259 (or $1.26 \%$ ). It means that the FEM model have error of $1.26 \%$ from theoritical method.
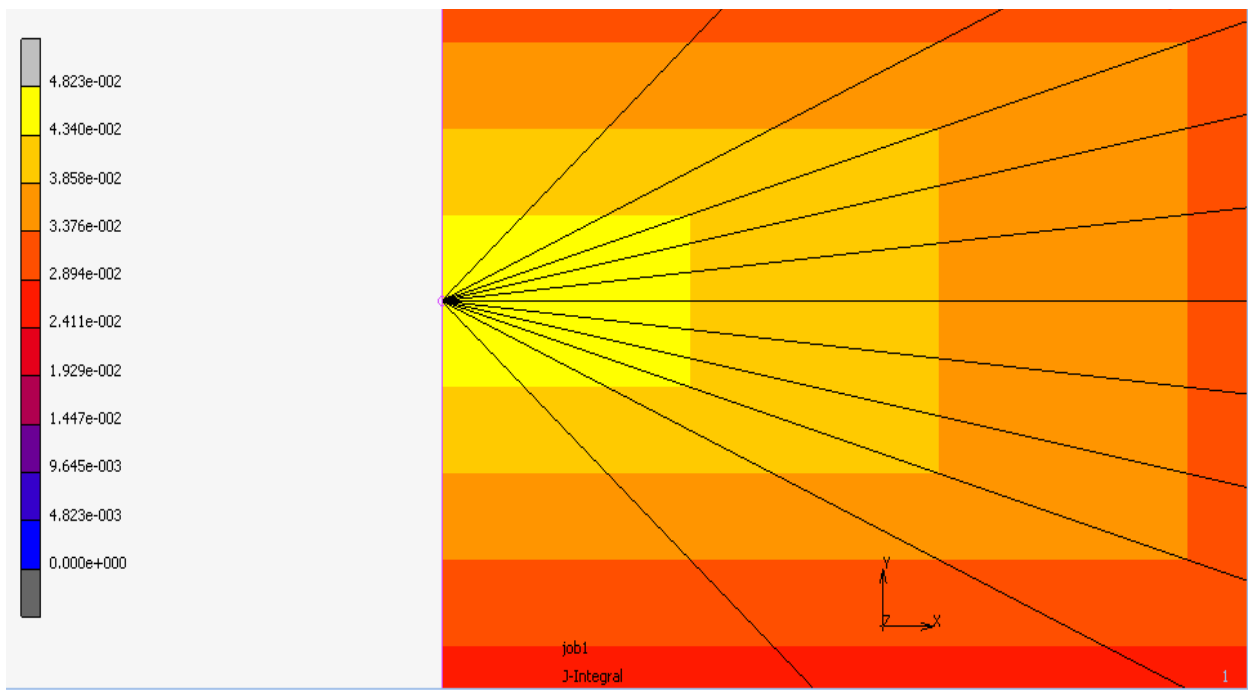

Figure 5. J Integral Result of The RPV wall.

Script phyton is used togenerate 20 samples of modulus of elasticity in normal distribution $(\mu, \sigma)$ with mean value $\mu=192000$, deviation $\sigma=9600$, and 20 samples of loading in uniform distribution (min, $\max$ ) to the minimum value of 14 and maximum value of 17 . The generated 
samples are presented in Table 1[14]. The result of 20 generations of these samples will be used for the calculation of $\mathrm{J}$ integral probabilistic as shown in Table 2.

Table 1. Results of 20 samples Generation.

\begin{tabular}{cccccc}
\hline No & $\begin{array}{c}\text { Modulus of } \\
\text { Elasticity }\end{array}$ & Loading & No & $\begin{array}{c}\text { Modulus of } \\
\text { Elasticity }\end{array}$ & Loading \\
\hline 1 & 198684 & 15.8 & 11 & 199777 & 16.3 \\
2 & 186065 & 16.4 & 12 & 186028 & 16.1 \\
3 & 196010 & 16.8 & 13 & 189049 & 15.2 \\
4 & 196059 & 14.4 & 14 & 187868 & 16.1 \\
5 & 195114 & 15.2 & 15 & 183523 & 14.8 \\
6 & 201215 & 16.3 & 16 & 180714 & 14.3 \\
7 & 190514 & 15.6 & 17 & 198370 & 15.3 \\
8 & 184007 & 17.0 & 18 & 189354 & 16.6 \\
9 & 181663 & 14.7 & 19 & 201695 & 15.8 \\
10 & 186726 & 14.3 & 20 & 204134 & 16.9 \\
\hline
\end{tabular}

Based on probabilistic method for $\mathrm{J}$ integral calculation, the value of modulus of elasticity and loading are replaced with the values of the generation of the samples. The simulation results for $\mathrm{J}$ integral calculation by including the uncertainty of the inputs using the generation 20 sample with crack length $100 \mathrm{~mm}, 200 \mathrm{~mm}$ and $300 \mathrm{~mm}$ are presented in Table 2. Figure 6 shows $\mathrm{J}$ integral values of generated 20 samples for the crack length of $100 \mathrm{~mm}, 200 \mathrm{~mm}$ and $300 \mathrm{~mm}$. The longer the crack is, the bigger the $\mathrm{J}$ integral of the simulation will be.

Table 2. Results of Simulation 20 samples for J Integral Value

\begin{tabular}{cccc}
\hline Sample & \multicolumn{3}{c}{ J Integral } \\
\cline { 2 - 4 } & $\begin{array}{c}\text { Crack length } \\
100 \mathrm{~mm}\end{array}$ & $\begin{array}{c}\text { Crack length } \\
200 \mathrm{~mm}\end{array}$ & $\begin{array}{c}\text { Crack length } \\
300 \mathrm{~mm}\end{array}$ \\
\hline 1 & 0.012392 & 0.027957 & 0.05170 \\
2 & 0.014256 & 0.032163 & 0.05989 \\
3 & 0.014201 & 0.032039 & 0.05267 \\
4 & 0.011622 & 0.032031 & 0.04353 \\
5 & 0.011678 & 0.026347 & 0.04873 \\
6 & 0.013022 & 0.029380 & 0.05433 \\
7 & 0.012599 & 0.028424 & 0.05256 \\
8 & 0.012059 & 0.034946 & 0.06194 \\
9 & 0.011731 & 0.026467 & 0.04875 \\
10 & 0.010801 & 0.024367 & 0.04507 \\
11 & 0.013117 & 0.029593 & 0.05453 \\
12 & 0.013742 & 0.031003 & 0.05734 \\
13 & 0.012053 & 0.027190 & 0.05029 \\
14 & 0.013607 & 0.030700 & 0.05658 \\
15 & 0.011771 & 0.026556 & 0.04912 \\
16 & 0.011160 & 0.025178 & 0.04657 \\
17 & 0.011638 & 0.026257 & 0.04856 \\
18 & 0.014352 & 0.032380 & 0.05969 \\
19 & 0.012207 & 0.027539 & 0.05054 \\
20 & 0.013799 & 0.031131 & 0.05758 \\
\hline Total & 0.251807 & 0.581648 & 1.04997 \\
\hline Mean & 0.012590 & 0.029082 & 0.05250 \\
\hline & & &
\end{tabular}




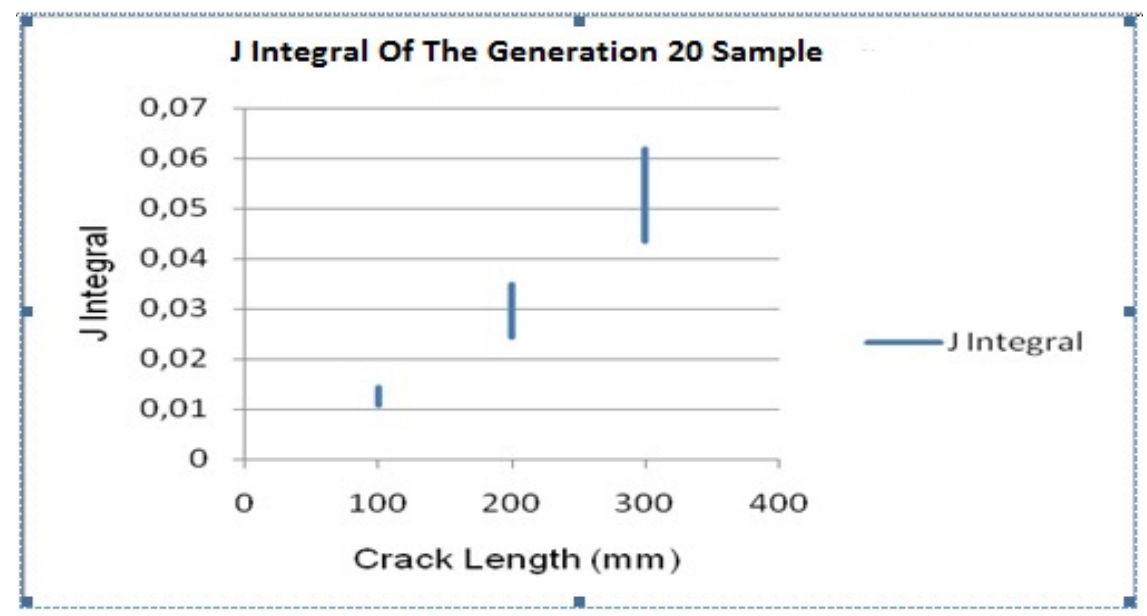

Figure 6. Simulation results of J Integral Calculation

The simulation was performed for three different crack length of $100 \mathrm{~mm}, 200 \mathrm{~mm}$ and 300 $\mathrm{mm}$. Figure 7 and Figure 8 present the value of $\mathrm{J}$ integral and Stress Intensity Factor (SIF) to crack length $100 \mathrm{~mm}$ to $300 \mathrm{~mm}$.

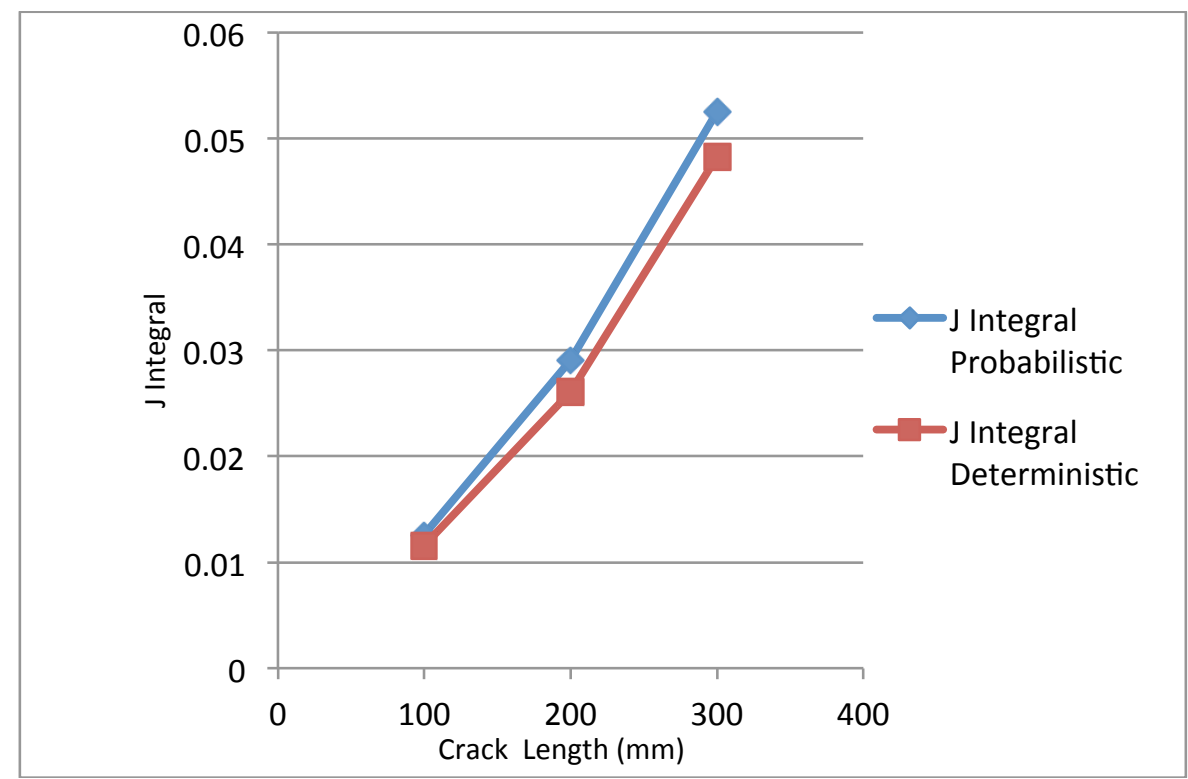

Figure 7. Results of J integral 


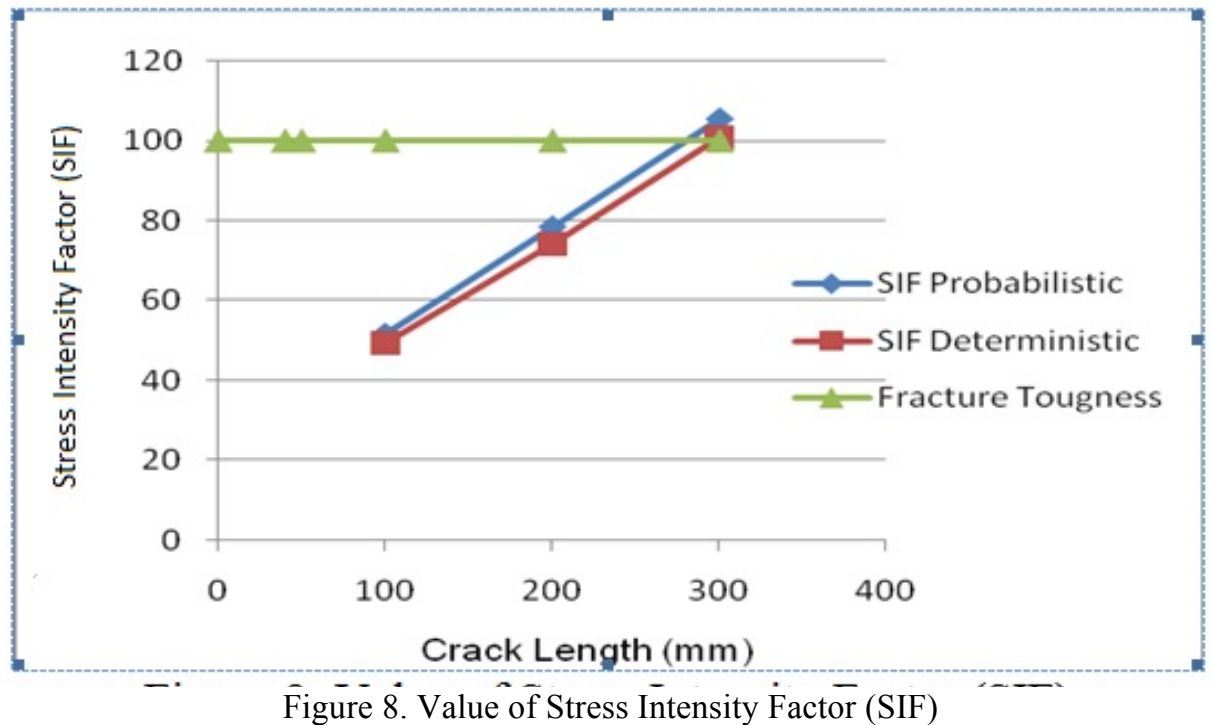

Figures 7 and 8 show that the result of $\mathrm{J}$ integral and stress intensity factor obtained by probabilistic method is greater than those obtained by deterministic method. The SIF from probabilistic method reached the limit value $\left(100 \mathrm{MPa} \mathrm{m}^{0.5}\right)$ of fracture toughness earlier than that of the deterministic method. The result from the deterministic and probabilistic calculation of $\mathrm{J}$ integral and SIF for crack length $300 \mathrm{~mm}$ is presented in Table 3.

Table 3. J Integral and Stress Intensity Factor Value for Crack Length $300 \mathrm{~mm}$

\begin{tabular}{lc}
\hline J Integral Types & SIF values \\
\hline J Integral Deterministic & 0.04823 \\
J integral probabilistic & 0.05250 \\
Stress Intensity Factor Deterministic (SIF & 100.876 \\
Det) & \\
Stress Intensity Factor Probabilistic & 105.240 \\
(SIF Prob) & \\
SIF Prob - SIF Det & 4.364 \\
Percentage Difference & $4.32 \%$ \\
\hline
\end{tabular}

Based on Table 3 at initial crack $300 \mathrm{~mm}$, SIF generated by the probabilistic method is 105.240 MPa m ${ }^{0.5}$. Meanwhile, the SIF generated by deterministic method is $100.876 \mathrm{MPa} \mathrm{m}^{0.5}$. The probabilistic SIF compared with deterministic SIF value is difference of $4.32 \%$.

The final results of this research were the value of stress intensity factor using deterministic and probabilistic method and for the evaluation of the reliability of PWR reactor pressure vessel.

\section{CONCLUSION}

The calculation of J Integral and stress intensity factor (2D) on the wall of the PWR pressure vessel using deterministic and probabilistic methods have been performed. From the result of calculation, it can be concluded that the SIF from probabilistic method reaches the limit value of fracture toughness earlier than SIF from deterministic method. The SIF generated by the probabilistic method is $105.240 \mathrm{MPa} \mathrm{m}^{0.5}$. Meanwhile, the SIF generated by deterministic method is $100.876 \mathrm{MPa} \mathrm{m}^{0.5}$. 


\section{ACKNOWLEDGMENT}

My appreciation to BATAN on the budget allocation in this research through DIPA PTKRN - BATAN 2015.

\section{REFERENCES}

1. Bo-Yi Chen, Chin-Cheng Huang, Hsoung-Wei Chou, Hsien-Chou Lin, Ru-Feng Liu, Tung-Li Weng, Han-Jou Chang, Reactor pressure vessel integrity assessment by probabilistic fracture mechanics a plant specific analysis, International Journal of Pressure Vessels and Piping 2014; 117:64-69.

2. Jose Martinez Trinidad, Didier Samayoa Ochoa, Erika Hermandez Garcia, Jose de Jesus Silva Lomeli, Orlando Susarrey, Huerta and alexander Balankin, Probabilistic fracture mechanics: Aplication in Reactor Pressure Vessel and Oil Pipelines, instituto politecnico Nacional, Revista Mexicana De Fisica 51 2005; p.19-29.

3. Shuxiao Li, Hailong Zhang, Shilei Li, Yanli Wang, Fei Xue, Xitao Wang, Probabilistic fracture mechanics analysis of thermally aged nuclear piping in a pressurized water reactor, Nuclear Engineering and Design 2013; 265:611-618.

4. Hans-Werner Viehrig, Eberhard Altstadt, Mario Houska, Matti Valo, Fracture mechanics characterisation of the beltline welding seam of the decommissioned WWER440 reactor pressure vessel of nuclear power plant Greifswald Unit 4, International Journal of Pressure Vessels and Piping 2012; 89:126-139.

5. Kunio Onizawa, Hiroyuki Nishikawa, Hiroto Itoh, Development of probabilistic fracture mechanics analysis codes for reactor pressure vessels and piping considering welding residual stress, International Journal of Pressure Vessels and Piping 2010; 87:2-10.

6. Shankar Sankararaman, You Ling, Sankaran Mahadevan, Uncertainty quantification and model validation of fatigue crack growth prediction, Department of Civil and Environmental Engineering, Vanderbilt University, Nashville, TN 37235, United States, Engineering Fracture Mechanics 2011; 78:1487-1504.

7. T.L.Anderson, "Fracture Mechanics Fundamental in Aplication", Taylor and Francis Boca Raton, New York, 2005.

8. F. González-Albuixech, G. Qian, M. Niffenegger, "Integrity analysis of reactor pressure vessels subjected to pressurizedthermal shocks by XFEMV”, Nuclear Engineering and Design 2014; 275:336-343.

9. Shankar Sankararaman, You Ling, Sankaran Mahadevan Uncertainty quantification and model validation of fatigue crack growth prediction, Engineering Fracture Mechanics 2011; 78:1487-1504.

10. Shankar Sankararaman, You Ling, Sankaran Mahadevan, Dusko Kancev, Gasper Zerovnik, Marko Cepin, Uncertainty analysis in the nuclear industry: Analytical unavailability modelling incorporating ageing of safety components, Journal of Loss Prevention in the Process Industries 2012; 25:643-649.

11. Miroslav Vorechovsky, "Hierarchical Refinement of Latin Hypercube Samples", Computer-Aided Civil and Infrastructure Engineering 2014; 29:1-18.

12. MSC Software "User's Guide Marc 2012”, USA, 2012.

13. A.Gopichand, Y.Srinivas, A.V.N.L. Sharma, Computation Of Stress Intensity Factor Of Brass Plate With Edge Crack Using J- Integral Technique, International Journal of Research in Engineering and Technology 2012; 01:261-266. 
14. Entin Hartini, Roziq Himawan, Uncertainty Analysis Software Development On The Structure Calculation of Materials (in Indonesia), Proceedings of the National Seminar of MIPA 2014, p.356-360.

15. S. Marie, Y. Menager and S. Chapuliot, Stress intensity factors for underclad and through clad defects in a reactor pressure vessel submitted to a pressurized thermal shock, International Journal of Pressure Vessels and Piping 205; 82:746-760. 